\title{
Identity Politics, Citizenship and the Soft State in Indonesia: an Essay
}

\author{
Henk Schulte Nordholt \\ KITLV Leiden/VU University Amsterdam
}

\begin{abstract}
Since 1998, administrative decentralisation, regional autonomy and ethnic and religious conflicts in areas outside Java have put identity politics high on the political agenda in Indonesia. This paper examines various expressions of these new identity politics and how they are related to, and derived from, older colonial concepts and categories. Examples from Riau and Bali illustrate how ethnic and religious repertoires are used to express political ambitions and mobilise popular support. Since 1998 Indonesia also witnessed a successful transition to electoral democracy. Whether democracy will take root in a more substantial way depends on the extent to which a notion of citizenship can be reinforced. It is argued that this notion of citizenship can only be maintained through the strengthening of the rule of law. In this respect it is also important to focus on the uneasy relationship between electoral democracy and ethnic and religious sentiments that tend to give far more attention to exclusive group interests while excluding a shared sense of citizenship. The paper concludes that democracy and citizenship, which are based on the rule of law, can only be achieved by strengthening the administrative and law-enforcing capacity of the state.
\end{abstract}

'Mana Indonesia oom?'

(Young boy in Kawal, island of Bintan, 21 April 2008) 


\section{Introduction}

Since May 1998, when Soeharto stepped down, Indonesia has undergone fundamental changes. More has been achieved than any of the wellinformed political observers of the late New Order dared to imagine. As far as I know, no one predicted at the start of 1998 that within the next decade there would be peace in Aceh; freedom of the press; a withdrawal of the armed forces from political and administrative institutions; no fear in giving voice to protest; economic recovery; constitutional reform, which makes the return of authoritarian rule unlikely; an electoral democracy that functions well; and far-reaching administrative decentralisation, giving way to regional autonomy, making an end to the centralist state.

Of course, each of these achievements has its dark side. In Aceh, some of the newly elected leaders who come from the Aceh Liberation Movement (GAM) [Gerakan Aceh Merdeka] tend to imitate the attitudes of their former military adversaries and, although the Indonesian army (TNI) [Tentara Nasional Indonesia] has lost much of its former influence, the armed forces are still relatively autonomous forces with their own sources of income. Despite economic recovery, conglomerates still structure the economy. Approximately half the population lives close to the poverty line and the quest for biofuels causes irreparable environmental damage. However, electoral democracy works and cases of corruption are exposed and prosecuted. For the time being corruption, not the rule of law, is still the main fuel keeping the political machine going.

When the authoritarian New Order regime fell apart, the state ideology, Pancasila, lost its near hegemonic authority and was challenged by a wave of religious, ethnic and regional identity politics. Because of democratisation and decentralisation, Reformasi intensified and accelerated these fragmented identities, which served as a means to mobilise new constituencies. The main victim of this process was, so it seemed, a shared sense of Indonesian citizenship. In the following pages I illustrate that the notion of citizenship was not only marginalised by the rise of ethnic and religious identity politics, it was also undermined by the failure of civil society groups to establish political alternatives. To conclude, I argue that democracy and citizenship both need a strong 
institutional setting, or state capacity, whereas Indonesia's present political configuration can be defined as a soft state.

\section{Civil War}

The demise of Soeharto's New Order between 1997 and 2002 was accompanied by unprecedented civil warfare in West and Central Kalimantan, Central Sulawesi, and the Moluccas, which was fuelled by religious and ethnic sentiments.

Initially three sets of explanations were heard at the seminars in Jakarta where activists and academics met to explain the sudden eruptions of violence. The first emphasised culture as the decisive factor. Cultural explanations tended to point at the primordial nature of the conflict between Dayak and Madurese people in Kalimantan. In this 'horizontal conflict' particular ethnic characteristics ('Madurese are violent', 'Dayak are head hunters') seemed to be sufficient to explain the violence. Here we see culture as the main actor, obscuring human agency. This perspective also represents the arrogant view of 'civilised' observers looking down upon the 'backwardness' of irrational cultures on the margins of Indonesia.

Another Jakarta-biased perspective had it that violence in the regions was orchestrated by particular groups ('the army', 'Cendana') operating at the national level and who used the unrest to serve their political interests. This approach denied the relevance of local agency and was to a large extent a reproduction of New Order thinking. Although external influences had an effect on local conflicts, they were not decisive.

Finally, attempts have been made to explain the violence purely in economic terms as rebellions by underprivileged groups (Dayak) against the exploitation of their natural resources, or as competition between immigrants (so-called BBM, Buginese, Butonese and Makassarese) and locals (Ambonese). The problem with this approach is that it does not explain why there was violence in particular places only and not 
elsewhere in the archipelago where there were similar economic and ethnic differences, and why this violence only took place at a particular moment in time and not at random.

Meanwhile, a growing number of studies has been conducted analysing specific cases of local conflict (see, for instance, Aragon 2001; Davidson 2008; Duncan 2005; Bubandt 2001; Spyer 2002; Tomagola 1999). Gerry van Klinken's book (2007a) is the first to offer a convincing comparative analysis of communal violence in Indonesia between 1997 and 2002.

Van Klinken contends that regional violence occurred during a period in which the power of the central state had temporarily collapsed. The weakening of state control in combination with democratic elections and far-reaching administrative decentralisation and regional autonomy caused unrest and fear but also opportunities. Because of the economic crisis, Jakarta was no longer able to finance the provincial and regional state apparatus. Consequently, regional elites no longer felt protected by their superiors in Jakarta and they lacked financial support from the centre as well. At the same time, decentralisation and democracy were on the way but the precise rules and regulations were not yet clear. This created an atmosphere of fear but also offered opportunities for ambitious local politicians. ${ }^{1}$

Under these conditions, communal violence turned into civil war in West and Central Kalimantan, Central Sulawesi and the Moluccas. Violence erupted in a particular type of provincial town, those that over the past decades had experienced rapid, but state-dependent, economic growth in combination with a high level of immigration. The result was an economy that depended to a large extent on state investments and government employment and in an urban setting that was highly diverse in terms of religion and ethnicity . Contrary to classical modernisation sociology, which argues that religious and ethnic differences fade as a result of processes of modernisation, ethnic and religious differences increased. In these highly volatile circumstances, urban elites tried to seize power in order to control local flows of money and to dominate

1 For a good analysis of local anxieties that led to the so-called ninja killings in East Java, see Herriman (2007). 
the changing political arena. The main actors who took these initiatives were, according to Van Klinken, influential politicians cum bureaucrats with good connections with local business people. In their efforts to gain power from 1998 onwards, they mobilised their religious or ethnic constituencies and in Central Sulawesi and the Moluccas accelerated a civil war that generated its own momentum (Van Klinken 2007a; Schulte Nordholt 2008: 129-46). ${ }^{2}$

Violence gradually decreased and eventually came to an end in the period 2001-02 because participants were exhausted and the central government intervened. A new consensus emerged-violence had been imported by outside agents who had managed to mislead the innocent local population. Generally, none of those who had initiated the fighting had succeeded in gaining powerful positions. Among the many casualties was the idea of a shared Indonesian citizenship. The religious conflicts in Central Sulawesi and the Moluccas sharpened divisions between Muslims and non-Muslims, but hardly anybody cared about the Madurese when they were driven out of Kalimantan. On the contrary, they were often blamed for the very violence that was inflicted upon them. ${ }^{3}$

These civil wars showed the ugly face of ethnic and religious identity politics in Indonesia. Decentralisation and democratisation did not always coincide with violence, but there was an overall increase in exclusive regional identity politics. Sometimes these were expressed in terms of adat, elsewhere it was a return to influence of the old sultanates.

\section{Adat and Aristocracy}

Adat, or customary law, was born in a colonial context when the Dutch tried to identify particular local customs, which were then fitted in a colonial regime. Adat also became a tool in the hands of conservative

2 John Sidel has offered another analysis of the same set of conflicts. In his book (2006) on religious violence in Indonesia, he presents a metanarrative of modernist and radical Islam wanting to expand its political influence. In so doing he obscures the aspect of agency and by and large ignores the ethnic violence in Kalimantan.

3 In a similar vein, very few people really cared for the victims of the civil war in Aceh. Influenced by a centralist perspective, they were primarily seen as separatists. It took a tsunami to bring Aceh back into Indonesia. 
colonial administrators who wanted to contain the spread of Islam and nationalism. In the late colonial state, adat denied modernity and became an ideological weapon against political innovation.

After independence adat lost its momentum and during the New Order it was further marginalised to the domain of folklore. After Soeharto stepped down there was a widespread revival of adat consciousness. Adat was seen as a moral alternative for the corrupt New Order regime and a device to reclaim land that had been confiscated by the state.

In 1999, AMAN [Aliansi Masyarakat Adat Nusantara] was established by urban NGOs who claimed to represent deprived 'adat communities'. The interests of 'local communities' and their 'traditional rights' were phrased in terms like 'grass roots,' bottom up' and 'empowerment'. The notion of 'adat community' resembled the term 'indigenous people', but this equation turned out to be highly problematic. For, do Papuans, Dayaks, people from Minangkabau and the Balinese belong in the same category? Balinese don't think so. Moreover, the notion of 'adat community' presumes homogeneous ethnic groups and denies the effect of urbanisation, migration and the impact of state institutions on local society. This raises the question of who actually belongs to the community and who is seen as an outsider. The emphasis on adat and adat communities creates the opportunity to exclude migrants and tends to increase gender inequalities within these 'communities'. Finally, there is the question of representation. Who speaks on behalf of the community and claims to represent their interests? These are usually urban intellectuals who sometimes use neocolonial stereotypes when they speak on behalf of their constituents. Sometimes money and power corrupt their activities, as Myrna Eindhoven (2007) has shown in the case of NGOs representing the interests of people on the Mentawai Islands. When leading figures from these NGOs started to participate in the local government they got involved in the very corrupt practices they had criticised not long before.

Apart from a revival of adat, we can also witness a return of local aristocracies; the sultans and rajas. Like adat, the position of regional aristocracies was also firmly rooted in the late colonial state when the Dutch established a system of indirect rule in which local aristocrats 
had to provide colonial authority with a familiar 'traditional' face. After independence most of these aristocracies were seen as conservative allies of the colonial state and they lost most of their power and influence.

After the fall of Soeharto, especially in areas outside Java, descendants of the old ruling families saw new opportunities to restore their former status. The moral bankruptcy of the New Order and regional autonomy offered opportunities for efforts to revive former sultanates and kerajaan, which represented a nostalgic longing for the good old days when people lived together in harmony under the benign leadership of local rulers. Corruption and the abuse of power, which had been intrinsic to the period of indirect rule, were erased from this romantic picture of the past (Van Klinken 2007b).

A group of recently revived rajas and sultans created the Forum Komunikasi Kraton-Kraton Indonesia. Apart from representing their interests at the national level, they visit each other regularly for important rituals. In September 2006, when the centenary of the colonial conquest of the south Balinese kingdom of Badung (puputan Badung) was commemorated, various delegations of aristocratic families from all over the archipelago attended the event. Among them was also a delegation from East Kalimantan dressed in colonial-style uniforms:

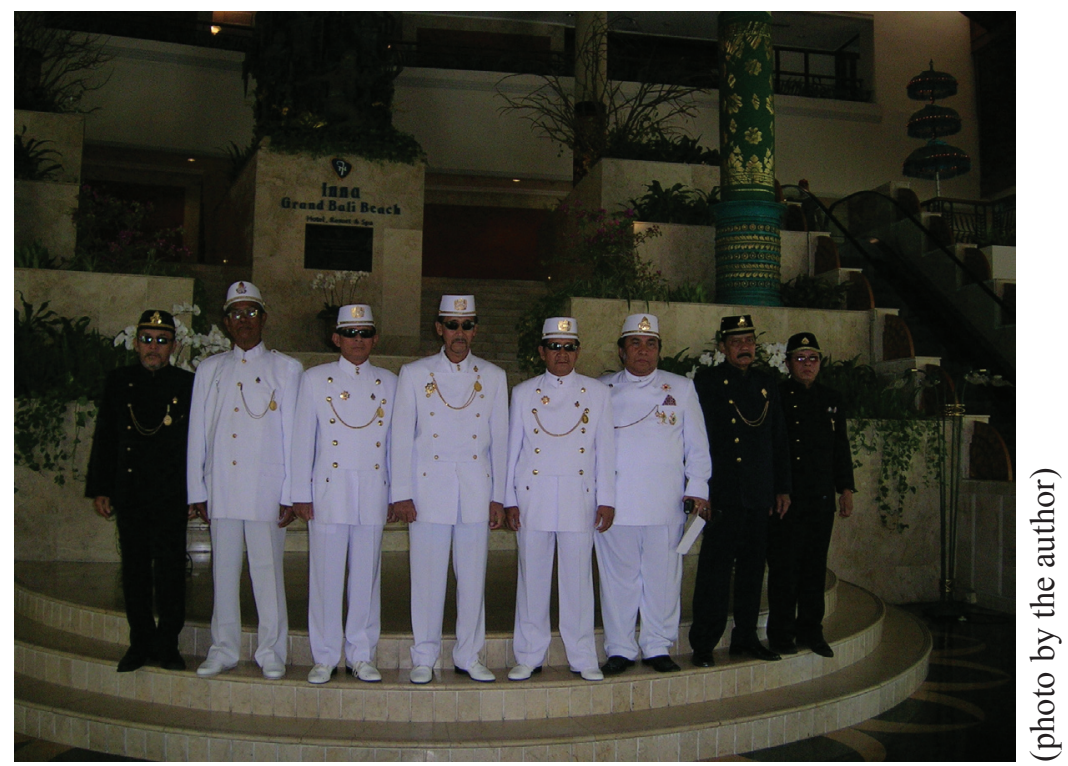


Adat and aristocracy are other sources of authority but at the same time represent a romantic nostalgia. What remains unclear is how adat and old aristocracies fit into a modern democracy. While some descendants of former rajas and sultans were used by ambitious administrators to give local culture more profile and stimulate tourism, others had political ambitions of their own. Among the latter was Sultan Mudaffar Syah from Ternate who played a central role in the civil war in the North Moluccas (1999-2001). In April 2006, he told me, 'We, the sultans and rajas, were the cornerstone of colonial rule in the archipelago. And in so doing we laid the foundation of present-day Indonesia. We made Indonesia. We represent, moreover, the cultural values of our people. And that is why we have the right to play a prominent role in contemporary Indonesia' (Schulte Nordholt 2008: 152). He tried to become governor of the new province of the North Moluccas but instead of trying to reconcile conflicting parties, he took sides and suffered a humiliating defeat (Van Klinken 2007a: 107-24).

Two examples, from Riau and Bali, illustrate the dilemmas that emerge in formulating local identities in the context of regional autonomy.

\section{Confusion in Riau}

The resource-rich province of Riau comprised until 2002 part of Sumatra and the Riau and Lingga archipelago. In addition to rubber and palm oil, half of Indonesia's oil production comes from this region, and the island of Batam has been transformed into a modern industrial zone. The province produced 14 per cent of Indonesia's GDP. At the same time, one third of the four million inhabitants lived below the poverty line because Jakarta took much and offered little.

When, in 1999, regional autonomy loomed, a 'declaration of sovereignty' was issued by Tabrani Rab, who also stated that his province might consider the possibility of becoming part of the United States of America. This did not happen, nor was the ambition realised to become, in economic terms, a second Brunei. Although local politicians had demanded that 70 per cent of the regional oil revenues flow to the province, they had to accept a share of 15 per cent. This was still enough to increase the provincial income six times. However, plans to establish 
a closer connection with neighbouring economic giant Singapore failed because of a process of administrative fragmentation. Apart from forming many new districts (known as pemekaran), politicians and administrators of the Riau and Lingga archipelago wanted to establish a province of their own, in which they succeeded in 2002. Much energy was invested in internal fights about the location for the new provincial capital and the building of a new administrative centre at Bintan Buyu for the kabupaten of the island of Bintan, and two successive district heads became involved in corruption scandals.

Meanwhile, heated debates were held about the identity of the newly established province of Kepri [Kepulauan Riau]. In the eyes of the old Malay elite, the identity of the province was closely tied to the history of the Malay sultanates. This would situate the province in a wider Malay world in which it would interact on equal footing with Malaysia and Singapore. In reality, however, Kepri was the poorest part of the economic triangle with Singapore and Johor, and was doomed to supply the other two with cheap labour. Many people in Riau resented the idea that Singapore looked down upon them.

The exclusive emphasis on an aristocratic Malay identity was also problematic because of the many Chinese and other immigrants who inhabit the province. Moreover, many young people felt no loyalty to or affection for high Malay culture whatsoever. At school the curriculum was set by the Indonesian government, and provincial youth preferred to watch Indonesian television programs made in Jakarta. Although the aristocratic elite dreamt of a Malay renaissance, young people felt more at home in a Jakarta-derived culture than in the intimidating high modernity of Singapore. Thus, in Riau, administrative fragmentation and contested identities resulted in conflict and confusion (Schulte Nordholt 2008: 153-5; Faucher 2007).

\section{Balinese Concerns}

In August 2003, a seminar was held in Bali to commemorate the 55 anniversary of the provincial newspaper, the Bali Post. The title of the meeting was 'Towards a strategy for a resilient Bali'. The intellectuals 
who attended the seminar tried to find a solution to three related dilemmas. The first concerned the fear that Balinese culture would be damaged by the hedonism, sex and drugs brought by Western tourists. A second concern was that the Balinese landscape might vanish as a result of uncontrolled building activities and especially the expansion of tourist resorts by Jakarta-based investors. At the same time, however, they realised that Bali was very much in need of the inflow of tourists because more than half the economy depended on tourism. Finally, there was an increased concern about the growing number of Muslim migrants from East Java and Lombok who find employment in the construction sector, as agrarian labourers and as street vendors. In Jakarta, when the organization of modernist Muslim intellectuals ICMI [Ikatatan Cendekiawan Muslim Indonesia] gained ground, the arrival of these migrants was perceived as a Muslim threat to Bali's Hinduism. However, the Balinese economy was highly dependent on cheap migrant labour from Lombok, which cost half as much as those from Bali.

There were more external threats. On 12 October 2002, a terrorist bombing in Legian killed more than 200 people and injured 300. On 1 October 2005, two minor explosions in Jimbaran and Kuta caused fewer casualties but again caused a dramatic decline in tourist arrivals. The effect on Hindu-Muslim relations of the bomb attack of October 2002 was less profound than expected. There was no violent revenge, although a tighter check on identity papers of Muslims migrants forced them to pay more bribes to renew their temporary work permits.

In November 2002, a large ritual was held on Legian beach to release the souls of the victims. Shortly afterwards the main perpetrators of the attack were arrested. This was done with the technical assistance of the Australian police, but many Balinese believed the terrorists were caught because of divine intervention. Their gods had beaten the Muslim terrorists.

New democratic elections and regional autonomy had a greater effect on Bali than terrorist attacks. Decentralisation resulted in administrative fragmentation while democratic elections caused a landslide victory for PDI-P. As a consequence, seasoned Golkar bureaucrats lost their 
hegemony and were replaced by a host of new and inexperienced administrators who were supported by noisy gangs of preman.

There was not only unrest at the district level but, within many villages, violent conflicts about caste and land (often called kasus adat) also increased. In addition, since the end of the 1990s, there had been an increase in thefts of holy objects from temples, which were widely ascribed to 'Javanese' or 'Muslims'. Many saw in these thefts a metaphor for Balinese culture, which was in danger and had to be protected against outside threats. The solution was found in a new, 'traditional', village police, the so-called pacalang, who were expected to protect Balinese culture.

The effort to defend Balinese culture is called Ajeg [resilient] Bali. Satria Narada, the leader of the Bali Post Group, who embodies the new moral leadership of a group of concerned urban intellectuals, plays a central role in it. His Ajeg Bali movement gained widespread support and emphasised the exclusively Hindu character of Balinese culture. Bali and Hindu became synonymous and, through the media of the Bali Post Group, the Ajeg Bali campaign took an anti-Muslim turn. In talk shows on Bali TV, guests appeared in full adat dress to explain the essence of Balinese culture, which was based on a romantic and conservative image of a supposedly authentic and unspoiled village Bali. Mirroring Muslim practices, the prayer puja trisandya was promoted as a late afternoon Hindu response to the adzan magrib; Balinese started to use the words 'om swastiastu' as an alternative for the Muslim greeting assalam aleikum; attempts were made to create a bakso Bali as part of a 'Hindu halal' cuisine. All these efforts made Muslims and migrants second-rate citizens.

Ajeg Bali was also supposed to become a new public Hindu-Balinese lifestyle rejecting political violence, gambling and alcohol and urging public administrators to cooperate. Ajeg Bali has become a container concept that incorporates a variety of interpretations. It became a mantra for concerned entrepreneurs in the tourism sector for whom culture is their capital, but it also offered many other people a new moral shelter. As one informant told me in April 2003, 'Ajeg Bali gives meaning to empty processes of modernisation; it strengthens our resilience.' 
Despite its flexible vagueness, Ajeg Bali has a rigid ethnic and religious agenda. Because the position of the old aristocracy has been weakened and caste hierarchy is contested, Ajeg Bali offers urban intellectuals and middle-class officials an opportunity to represent Bali as a homogeneous culture able to face external threats. At one and the same time the Ajeg Bali discourse erases conflicts concerning class, caste, religion and ethnicity.

The irony of the Ajeg Bali movement, and of similar movements led by concerned urban intellectuals elsewhere in the archipelago, is that it tends to stress regional identity and authenticity in a very Indonesian way. All over Indonesia regional differences are increasingly expressed in similar terms at seminars where exclusive local identities are expressed in a uniform format, which is characterised by a mixture of old colonial concepts phrased in post-New Order bureaucratic language (Schulte Nordholt 2007).

\section{The Failure of Civil Society}

Like other ethnic movements, Ajeg Bali tends not to engage in a broader discourse about Indonesian citizenship, which forms the very basis of democracy. Citizenship concerns the relations between citizens and the state and their mutual rights and obligations. It is based on the rule of law, emphasises justice and equality, and forms the very foundation of a democracy. In short, citizenship is what makes people in Indonesia into Indonesians.

The notion of citizenship was not only threatened by the exclusive nature of ethnic and regional sentiments but also by the failure of civil society groups to establish strong political alternatives when Reformasi offered opportunities to do so. In this respect, it is interesting to note that there has been more discussion about the empowerment of civil society than the strengthening of citizenship in Indonesia.

There were (and still are) literally thousands of civil society organisations, or NGOs, in Indonesia, many of whom have received financial support from Western countries. After 1998, not one of 
these managed to transform itself into a new political party that could contribute in a meaningful way to the development of a new democratic system. Why this is so is a question rarely asked but one that deserves serious attention.

At the conference, 'Indonesia Ten Years After, Prospects and Constraints', which was held in Amsterdam on 22-23 May 2008, an attempt was made to formulate some preliminary answers, which will be summarised here. ${ }^{4}$ It should be emphasised that these are preliminary notes that deserve further discussion.

1. Many activists did move into politics after 1998 but they went into existing political parties where many of them managed to have a career. In so doing they had to compromise and they failed to make a difference.

2. Most activists, however, refrained from moving into politics. They considered political parties centres of evil practices and decided to stay ideologically clean. This attitude was reinforced by a conceptual differentiation between civil society as a repository of morally good behaviour on the one hand and the state and politics as sources of violence and corruption on the other.

3. The inability to establish a political alternative in the political domain had also to do with the way NGOs functioned. Many depended largely on external funding and lacked the autonomy to set their own agenda and long-term objectives. Often, foreign donors demanded that NGOs stay away from politics and concentrate on socio-economic topics.

4. Most NGOs focused, moreover, on particular issues (called isu) and were often single-issue organisations. They lacked therefore a wider perspective on broader political themes.

5. Within their respective niche, NGOs had to compete with other civil society organisations to obtain foreign funding and this often prevented cooperation between them.

6. Another factor that fragmented civil society was that many NGOs were rooted in different aliran, or specific socio-cultural groups, in

4 The conference was organised by KITLV, Inside Indonesia and the University of Amsterdam; see on this theme also Priyono et al. (eds.) (2007). 
society. Apparently it took a lot of effort to cross boundaries within civil society to cooperate more closely.

7. The way NGOs are structured as foundations prevents internal transparency and undermines democratic decision making. The fact that a limited number of people make the important decisions, excludes other participants and encourages an internal 'strong man culture'.

8. Often, civil society is mistakenly portrayed as a single, homogeneous field. In practice this is not the case, as Eva-Lotta Hedman has demonstrated in her book on the Philippines (2006), because class differences do matter. The fact that many NGOs are dominated by people with a middle-class background influences the way the interests of lower classes are represented. Representation means 'to speak on behalf of' as well as 'to conceptualise'. In both meanings, middle-class NGO perspectives of lower classes often reflect a combination of ignorance and arrogance. This may take various forms. Lower classes are, for instance, depicted as 'still' underdeveloped, or 'not yet' able to speak for themselves, which causes them to lack, according to this view, agency and they therefore have to be represented.

9. Because the Indonesian middle classes grew up during, and were socialised by, the New Order state, it can be argued that many ideas and attitudes of NGOs were very much influenced by New Order perspectives about the so-called 'floating masses' (cf. Priyono et al. 2007). If this is true, one may also question the relevance of the conceptual distinction between the state and civil society.

10. Finally, many NGOs are not exclusively focused on the nation-state because they operate in international networks and participate in programs with a transnational character. ${ }^{5}$

If we take the deficiencies of civil society organisations vis-a-vis politics into consideration, we can conclude that in general the contribution of NGOs to democratisation in Indonesia is restricted to specific issues. Therefore Indonesia could be characterised as 'a single-issue democracy' in which larger questions concerning citizenship are still by and large ignored.

5 See Connor and Vickers (2003). 


\section{PKS, an Islamic Exception?}

There is one important exception to the failure of civil society organisations to produce a political alternative: Partai Keadilan Sejahtera. PKS has its roots in the campus dakwah, or missionary (movement with its many tarbiyah or study groups). With financial support from the Middle East — and not funded by any of the major Western donors - this grass roots movement developed a well-trained cadre and a long-term agenda. The first attempt to move into politics in 1999 failed when Partai Keadilan put too much emphasis on the implementation of the shari' $a$ and obtained only 1.3 per cent of the vote. A new attempt in 2004 had more success when the issue of corruption was emphasised in the campaign. This time PKS managed to win 7 per cent of the votes and obtain 45 seats in parliament. PKS is clearly an Islamic party but it decided to operate within a democratic system and is therefore also willing to compromise. Outside the parliament, PKS actively participated in relief work and other social activities, which gave the party a strong public profile (Schulte Nordholt 2008:182-84).

More recently, PKS has tried to expand its constituency by advocating more openness, while downplaying the urgency of the implementing the shari' $a$. By adopting a less ideological and more practical approach, PKS also wants to build alliances with non-Islamist partners. This development is criticised by hardliners within the party. It therefore remains to be seen whether PKS will succeed in becoming a major player in the political arena in Indonesia.

Although the civil wars between Protestants and Muslims in Poso and the Moluccas came to an end, religious conflicts are not over. A recent report by the International Crisis Group (2008) warns of rising tensions between Muslims and Christians in West Papua, and government measures against the Ahmadiyah seem to legitimise the hostility to this group by a minority of Indonesian Muslims (Tempo 41/2008, x10-16 June). The tensions in Papua and the pogroms against the Ahmadiyah illustrate how fragile citizenship is in contemporary Indonesia. ${ }^{6}$

6 See, however, Azra and Hudson (2008) for a serious discussion about the relationship between Islam and citizenship in Indonesia. 


\section{Democracy and Citizenship}

A decade ago the Orde Baru was classified as one of the most authoritarian regimes, but today Indonesia is the third largest democracy in the world. One of the greatest achievements of the past decade is that electoral democracy has been established in Indonesia. People participate with enthusiasm in fair elections at the national, provincial and district levels. However, fair elections are not synonymous with institutionalised democracy based on the rule of law and characterised by transparency and accountability. Dan Slater (2004) has suggested that electoral democracy is neutralised by broad alliances of party leaders who create political cartels in which they distribute power and access to state resources among themselves. Similarly, Vedi Hadiz (2008) has argued that economic power is still in the hands of entrenched elites and the economic process is fuelled by corruption. The extent to which members of representative bodies like the national parliament (DPR) [Dewan Perwakilan Rakyat] and regional councils (DPD) [Dewan Perwakilan Daerah] identify with the executive power is illustrated by the fact that they see their job primarily as a means to gain access to state funds. Few consider the relationship with their constituencies and the exercise of democratic control as their prime tasks. Symbols of their newly acquired power include cars, houses and the notorious studi banding, or study trips, to tourist destinations, which are hardly relevant for their daily work in parliament.

Despite these negative remarks, it cannot be denied that electoral democracy offers an opportunity to defeat candidates with a military background or incumbent administrators who want to be re-elected but have been involved too much in corruption. Marcus Mietzner (2005) has calculated that 40 per cent of the incumbents were not re-elected during the district elections of 2005. Moreover, recent elections for a new governor in the provinces of West Java and North Sumatra showed that people are tired of the old political establishment consisting of former military and Golkar and PDI-P elites, who were defeated by coalitions of small parties that promised renewal and anti-corruption measures. It is interesting that in both coalitions PKS played a prominent role. 
Direct elections at the district and provincial level also tend to blur ethnic boundaries as candidates try to cross these lines to expand their constituencies. In Central Kalimantan, a candidate who was known as a 'Dayak extremist' was defeated, and in south Bali several candidates sought support among Muslim migrant communities. In many places where Muslims and Christians live together, candidates belonging to one religion chose their running mate from the other.

Even though corrupt administrators and ethnic diehards were defeated not everybody could run for office. Most candidates who managed to win elections were often combinations of experienced bureaucrats and wealthy businessmen, which signals the emergence of a new political class at the regional level.

The most important vehicles of democracy are political parties. Compared with neighbouring countries like Thailand and the Philippines, Indonesian political parties show a high degree of continuity, which seems to guarantee a measure of stability (Ufen 2008). However, most party organisations are undemocratic and exclusively focused on the interests of their leaders without paying much attention to the interests of their constituents. Corrupt practices have increased because government support for political parties was reduced in June 2005 and parties were forced to look for 'alternative sources of income' to finance the ongoing process of elections in the archipelago (Mietzner 2007).

Two other factors help to undermine party stability. In the first place the power of political parties is challenged at the regional level by independent candidates who are allowed to run for office. ${ }^{7}$ A second factor is the recent tendency to mobilise political support through religious gatherings, called dhikr bersama. These gatherings are often sponsored by political leaders and serve to enhance a sense of community. Because the political agenda of these meetings is not explicitly expressed, they tend to depoliticise society by replacing the role of political parties by these seemingly apolitical feel-good gatherings. ${ }^{8}$

7 Law 12/2008; personal communication from Michael Buehler.

8 Personal communication from Noorhaidi Hasan. 
Electoral democracy by itself does not guarantee the democratisation of the political system. Under the present conditions it will at best reinforce a patrimonial democracy in which leaders use elections to strengthen their power, in exchange for which followers hope get access to state resources.

\section{Citizenship and the State}

Without a strong sense of citizenship, the state is perceived as a source of wealth instead of a provider of justice. It was one of the biggest mistakes of neo-liberal ideology to think that less state would lead to more democracy because democracy has to be embedded in reliable state institutions (Schulte Nordholt 2004; see also Suleiman 2003). If the state does not perform its task of guaranteeing the rule of law, how can people be persuaded to participate in elections? For how many elections to come will voters still be motivated to defeat corrupt administrators if, following an election, they get yet another corrupt administrator? In this respect it is shocking to note that there is still in Indonesia a culture of impunity, which also favours a denial of responsibility. When in April this year, Eurico Guterres was acquitted of charges of violating human rights, one could conclude that future generations would learn that eventually no-one would be held responsible for the atrocities in East Timor in September 1999. Similarly, General Muchdi initially got away with his statement that he was not responsible for the phone calls to Pollycarpus made with his mobile phone shortly before human rights activist Munir was killed in September 2004 (Schulte Nordholt 2008: 246-8). On 19 June, however, General Muchdi was arrested as a suspect in the Munir murder.

In his recent book on the history of the idea of Indonesia, Robert Elson (2008) concludes that a strong national identity failed to appear. After 1998, the elite was not capable of providing a new sense of what the idea of Indonesia represented (2008:280). This is illustrated by the question 'Mana Indonesia, oom?' asked by a schoolboy in Kawal. Elson also concludes that democracy has been appropriated by those already in power. He points primarily at the inability to articulate a strong national identity, which results in disillusionment in the nation as a meaningful 
entity (2008: 312). It makes more sense to be a Muslim, a Batak or a Balinese than to believe in 'Indonesia'. This is only half the story because citizenship is not only rooted in the nation but also embedded in the state.

During the New Order, Indonesia was depicted as an authoritarian state. Power was efficiently concentrated in the centre but, seen in quantitative terms, the state itself was not very large (Barker and Van Klinken 2007). After 1998, the state lost much of its administrative capacity and took the shape of a soft state, which is characterised by the fact that many of its regulations are ignored. A comparison between Indonesia and the Netherlands illustrates the relative weakness of the Indonesian state: Indonesia has about 230 million inhabitants and a national budget of USD 108 billion, whereas the Netherlands, with only 16 million inhabitants, has a budget three times greater, that is, USD325 billion.

Electoral democracy has been established but the future of democracy in Indonesia will depend on the capacity of the state to guarantee the rule of law. Whereas the new political elites see the state primarily as a resource through which they can feed their clients, democracy requires more state capacity through which the rule of law and citizenship can be strengthened. This cannot be achieved overnight, it will take decades to improve the quality of the state to strengthen Indonesian citizenship.

\section{References}

\section{Books and Journals}

Aragon, Lorraine. 2001. 'Communal Violence in Poso, Central Sulawesi, Where People Eat Fish and Fish Eat People'. Indonesia 72: 45-79.

Azra, Azyumardi and Wayne Hudson (eds). 2008. Islam Beyond Conflict: Indonesian Islam and Western Political Theory. Aldershot: Ashgate.

Barker, Joshua and Gerry van Klinken. 2007. 'State and Society in Indonesia'. Unpublished.

Bubandt, Nils. 2001. 'Decentralisation, Conflict, and the New Politics of Tradition in North Maluku'. Copenhagen: NIAS.

Connor, Linda and Adrian Vickers. 2003. 'Crisis, Citizenship and Cosmopolitanism: Living in a Local and Global Risk Society in Bali’. Indonesia 75: 153-180. 
Davidson, Jamie. 2008. From Rebellion to Riots: Collective Violence on Indonesian Borneo. Madison: University of Wisconsin Press.

Duncan, Christopher. 2005. 'The other Maluku: Chronologies of Conflict in North Maluku'. Indonesia 60: 53-80.

Eindhoven, Myrna. 2007. 'New Colonizers? Identity, Representation and Government in post-New Order Mentawai Archipelago', in H Schulte Nordholt and $\mathrm{G}$ van Klinken (eds). Renegotiating Boundaries: Local Politics in post-Suharto Indonesia. Leiden: KITLV Press, pp. 67-89.

Elson, RE. 2008. The Idea of Indonesia: a History. Cambridge: Cambridge University Press.

Faucher, Carole. 2007. 'Contesting Boundaries in the Riau archipelago', in H Schulte Nordholt and G van Klinken (eds). Renegotiating Boundaries: Local Politics in post-Suharto Indonesia. Leiden: KITLV Press, pp. 443-58.

Hadiz, Vedi. 2008. 'How Far to Meaningful Democracy'. Inside Indonesia 92.

Hedman, Eva-Lotte. 2006. In the Name of Civil Society: From Free Election Movements to People Power in the Philippines. Honolulu: University of Hawai'i Press.

Herriman, Nicholas. 2007. 'A Din of Whispers: Community, State Control and Violence in Indonesia'. PhD thesis. University of Western Australia.

International Crisis Group (ICG). 2008. 'Indonesia: Communal Tension in Papua'. Brussels/Jakarta: Asia Report 154.

Klinken, Gerry van. 2007a. Communal Violence and Democratization in Indonesia: Small Town Wars. London/New York: Routledge.

-------. 2007b. 'The return of the Sultans: the Communitarian Turn in Local Politics', in J Davidson and D Henley (eds). The Revival of Tradition in Indonesian Politics: the Development of Adat from Colonialism to Indigenism. New York: Routledge, pp. 149-69.

Mietzner, Marcus. 2005. 'Local Democracy'. Inside Indonesia 85.

-------. 2007. 'Party Financing in post-Soeharto Indonesia: Between State Subsidy and Political Corruption'. Contemporary Southeast Asia 29: 238-63.

Priyono AE, Willy Purna Samadhi, Olle Törnquist et al. (eds). 2007. Making Democracy Meaningful: Problems and Options in Indonesia. Yogyakarta: PCD Press.

Schulte Nordholt, Henk. 2004. 'Decentralisation in Indonesia: Less State, More Democracy?' in John Harris, Kristian Stokke and Olle Törnquist (eds). Politicising Democracy: the new local politics of democratization. New York: Palgrave, pp. 29-50.

2007. Bali an Open Fortress 1995-2005: Regional Autonomy, Electoral Democracy and Entrenched Identities. Singapore: NUS Press.

2008. Indonesië na Soeharto: Reformasi en Restauratie. Amsterdam: Bert Bakker.

Sidel, John. 2006. Riots, Pogroms, Jihad: Religious Violence in Indonesia. Ithaca/ London: Cornell University Press.

Slater, Dan. 2004. 'Indonesia's accountability trap: Party cartels and presidential power after democratic transition'. Indonesia 78: 61-92.

Spyer, Patricia. 2002. 'Fire without Smoke and Other Phantoms of Ambon's Violence: 
Media Effect, Agency and the Work of Imagination'. Indonesia 74: 21-36.

Suleiman, Ezra. 2003. Dismantling Democratic States. Princeton/Oxford: Princeton University Press.

Tomagola, TA. 1999. 'Tragedi Maluku Utara'. Masyarakat Indonesia 25: 289-302.

Ufen, Andreas. 2008. 'Roots of democracy'. Inside Indonesia 92. 